\title{
Märehtijöiden valkuaisarvojärjestelmä (OIV-PVT) uudistuu
}

Pekka Huhtanen

Ruotsin Maatalousyliopisto (SLU), S-901 83 Uumaja, Ruotsi, etunimi.sukunimi@njv.slu.se

\section{Tiivistelmä}

Suomessa ohutsuolesta imeytyviin aminohappoihin perustuva rehuvalkuaisen arviointijärjestelmä (OIV-PVT) on ollut käytössä noin 15 vuotta. Tänä aikana järjestelmään on tehty vähäisiä muutoksia, lähinnä joidenkin rehujen hajoavuusarvoja on tarkistettu ja ruokintasuosituksia muutettu. Kaikissa rehuvalkuaisen arviointijärjestelmien vertailuissa Suomen systeemi on osoittautunut parhaaksi, kun kriteerinä käytetään lypsylehmien valkuaistuotoksen ennustamista.

Ehdotetun uudistuksen taustalla on uusin tutkimustieto pötsin valkuaismetaboliasta. Laajaan tuotantokoeaineistoon (992 ruokintaa) perustuen analysoitiin, miten eri vaihtoehdot mikrobisynteesin laskentamallissa vaikuttavat valkuaistuotoksen ennustevirheeseen. Lisäksi analysoitiin, miten valkuaistuotoksen ennustevirhe muuttuisi, jos rehuvalkuaiselle käytettäisiin vakiohajoavuutta pötsissä.

Mikrobivalkuaisen laskemisessa parhaaksi osoittautui ylläpitotasolla laskettu sulavan orgaanisen aineen saanti, josta vähennetään pötsissä hajoamaton valkuainen. Muut korjaukset (säilörehun käymishapot, rasva) joko yksinään tai yhdessä muiden kanssa huononsivat ennustetta, vaikka teoriassa näiden vähentäminen mikrobeille käyttökelpoisesta substraatista olisi perusteltua. Synteesin tehokkuusluku per kg korjattua sulavaa orgaanista ainetta kohti on $152 \mathrm{~g}$ ja se perustuu satakertatekniikalla määritettyyn dataan. Mikrobisynteesin tehokkuus paranee ruokintatason noustessa, mutta tämän huomioon ottaminen mallissa lisäsi hieman ennustevirhettä. Mallin monimutkaistaminen ottamalla huomioon sekä lisääntyvä mikrobisynteesin tehokkuus että huononeva rehun sulavuus ei siten ole perusteltua. Uuden alemman synteesitehokkuuden vuoksi todellinen valkuaistase on nolla silloin kun laskennallinen tase on nolla eli nykysysteemin yksi ongelma poistuu. Pötsin todellinen valkuaistase on nolla maidon ureapitoisuuden ollessa noin $18 \mathrm{mg} / 100 \mathrm{ml}$. Aminohappojen osuudeksi mikrobivalkuaisesta ehdotetaan MTT:n tutkimusten perusteella $75 \%$ aikaisemman $70 \%$ sijasta.

Valkuaisen pötsihajoavuuden vaikutus valkuaistuotokseen ja typen hyväksikäyttöön oli varsin pieni, kun se lisättiin ennustemalliin energian ja raakavalkuaisen saannin lisäksi, näin erityisesti kun hajoavuusarvot perustuivat yksinomaan nailonpussimenetelmällä määritettyihin parametreihin ja yleisesti käytössä olevaan kinetiikkamalliin. Satakerta-aineiston analyysi osoitti, että todelliset erot rehuvalkuaisen pötsihajoavuudessa ovat selvästi määritettyjä eroja pienempiä. Osittain virhe johtuu siitä, että ns. nopeasti hajoavan valkuaisen sulatusnopeuden on oletettu olevan ääretön. Useilla eri tutkimusmenetelmillä ja myös tuotantokoe-aineistojen meta-analyyseillä on osoitettu, että pötsistä virtaa rehusta peräisin olevaa aminotyppeä (vapaat aminohapot, peptidit, liukoinen valkuainen) nestefaasissa. Toisaalta kinetiikkamallin oletus satunnaisesta rehupartikkeleiden virtauksesta ei pidä paikkaansa ja rehun todellinen viipymisaika pötsissä on mallin oletuksia pitempi, jolloin liukenemattomasta valkuaisesta hajoaa pötsissä oletettua enemmän. Yhteenvetona näistä voi todeta, että osa oletetusta hajoavasta valkuaisesta on hajoamatonta ja vastaavasti osa hajoamattomasta hajoaa pötsissä oikean, mallin olettamuksia pitemmän viipymisajan vuoksi. Nämä tekijät vaikuttavat samaan suuntaan vähentäen rehujen välisiä eroja valkuaisen pötsihajoavuudessa verrattuna pussimenetelmän ja käytetyn kinetiikkamallin arvoihin. Näiden tekijöiden vaikutukset otettiin ainakin osittain huomioon, kun OIV-PVT järjestelmä otettiin käyttöön Suomessa käyttämällä muita systeemejä pitempiä ja paremmin todellisuutta vastaavia rehun viipymisaikoja valkuaisen pötsihajoavuusarvoja laskettaessa. Kovin suuria menetyksiä rehuvalkuaisen arvioinnissa ei tapahtuisi, vaikka rehukohtaisten hajoavuuksien sijasta luokiteltaisiin rehut 3-4 hajoavuusluokkaan. On syytä mainita, että pelkästään nailonpussihajoavuuksiin perustuvissa systeemeissä vakiohajoavuus kaikille rehuille vähentää ennustevirhettä rehukohtaisten arvojen käyttöön verrattuna eli määritettyjen arvojen virhe on keskimäärin suurempi kuin vakioarvojen. Valkuaisjärjestelmien parantaminen hajoamattoman rehuvalkuaisen osalta edellyttää, että tutkijat kehittävät menetelmän, jolla hajoavuudet ja niiden erot pystytään kvantitatiivisesti määrittämään. Nykyisellään hajoavuusarvoja ei ole tarpeen uudistaa; edelleen on mahdollista saada rehulle hyväksytyksi parempi valkuaisarvo, kun se pystytään osoittamaan todeksi tuotantokokeessa. Pussimenetelmän epäluotettavuuden vuoksi tämä käytäntö on perusteltu etenkin pyrittäessä prosessoinnein alentamaan hajoavuutta.

Asiasanat: Rehuvalkuaisen arviointi, mikrobivalkuainen, ohitusvalkuainen, lypsylehmä 


\section{Johdanto}

Märehtijöiden rehujen valkuaisarvo määritettiin aikaisemmin sulavana raakavalkuaisena (SRV). Noin vuodesta 1980 lähtien eri maissa ruvettiin siirtymään SRV:stä järjestelmiin, jotka perustuvat ohutsuolesta imeytyvien aminohappojen määrään. Yhteisellä nimellä näitä voidaan kutsua muuntokelpoiseen valkuaiseen (MP) perustuviksi järjestelmiksi. Järjestelmien ja yksiköiden nimet voivat vaihdella, mutta yhteistä niille on se, että ne ottavat erikseen huomioon pötsimikrobien typen (hajoavan valkuaisen) tarpeen ja isäntäeläimen aminohappojen tarpeen. Pohjoismainen AAT-PBV - järjestelmä esitettiin 1985 (Madsen, 1985). Suomessa järjestelmä otettiin virallisesti käyttöön 1995. AAT-PBV:tä vastaavat suomaiset termit ovat OIV (ohutsuolesta imeytyvä valkuainen) ja PVT (pötsin valkuaistase).

Pötsissä muodostunut mikrobivalkuainen ja pötsin hajoamatta ohittava rehuvalkuainen ovat märehtijöiden tärkeimmät aminohappojen lähteet. Lisäksi jotkut systeemi (esim. NRC, 2001) ottavat huomioon ohutsuolesta takaisin imeytyvän endogeenisen valkuaisen.

Uudet järjestelmät ennustavat ruokintojen väliset erot maitovalkuaisen tuotannossa selvästi paremmin kuin SRV. Lähes 300 ruokintaan perustuvassa vertailussa SRV (Huhtanen 2005) ennusti maitovalkuaistuotannon jopa huonommin kuin pelkkä raakavalkuainen (RV). Muuntokelpoisen energian (ME) saanti ja jopa kuiva-aineen syönti ennustivat maitovalkuaisen tuotannon paremmin kuin SRV tai RV, mikä osoittaa mikrobivalkuaisen keskeisen roolin imeytyvien aminohappojen saannissa.

Suomen OIV-PVT -systeemissä (Tuori ym. 1998) mikrobivalkuaisen osuus OIV:n saannissa on suurempi kuin alkuperäisessä skandinaavisessa systeemissä, vaihtelu rehuvalkuaisen hajoavuudessa vähäisempää ja hajoamattoman rehuvalkuaisen sulavuus ohutsuolessa vakio. Systeemin validointi tuotantokoeaineistolla (157 ruokintaa) osoitti, että poikkeamat alkuperäisestä systeemistä pienensivät valkuaistuotoksen ennustevirhettä. Myöhemmässä vertailussa (Schwab ym. 2006) Suomen OIV-PVT systeemi ennusti rajoitetulla (72 ruokintaa), mutta monipuolisella suomalaisella ruokintakoeaineistolla ruokintojen väliset erot maitovalkuaisen tuotannossa paremmin kuin muut vertailussa olleet järjestelmät. Myöhemmät vertailut ovat vahvistaneet Suomen OIV-PVT -systeemin paremmuuden. Suomessa käytössä olleen systeemin suurin virhe on ollut mikrobisynteesin tehokkuusarvo, joka johtaa liian pieniin laskennallisiin PVT-arvoihin. Tämä johtuu siitä, että mikrobisynteesiä laskettaessa myös pötsissä hajoava valkuainen otettiin mukaan sulavien hiilihydraattien kanssa samanarvoisena, mutta synteesin tehokkuusluku (179) pidettiin samana kuin alkuperäisessä skandinaavisessa systeemissä. Käytännön ruokinnan suunnittelussa tästä ei kuitenkaan aiheutunut pitempään ongelmia, kun PVT:n tarpeeksi asetettiin >-20 g syötyä kg kuiva-ainetta (KA) kohti eli esimerkiksi 20 kg KA päivässä syövällä lehmällä PVT sai olla $-400 \mathrm{~g} / \mathrm{pv}$.

Sen jälkeen kuin OIV-PVT -systeemi otettiin Suomessa virallisesti käyttöön, märehtijöiden valkuaisruokinnasta on tullut runsaasti uutta tietoa. Tämän artikkelin tavoitteena on tarkastella OIV:n saantiin vaikuttavia tekijöitä ja miten uusin tutkimustieto voidaan hyödyntää OIV-PVT -järjestelmän päivityksessä.

\section{Mikrobivalkuainen}

Pötsissä mikrobien syntetisoima valkuainen on ylivoimaisesti tärkein märehtijöiden aminohappojen saannin lähde. Kun hajoavaan valkuaista (RDP) on riittävästi, mikrobivalkuaisen tuotanto pötsissä riippuu pääasiassa käymisessä vapautuneessa mikrobeille käyttökelpoisesta energiasta (ATP). Koska ATP:n tuotantoa ei käytännössä voida mitata, mikrobisynteesin tehokkuus on eri valkuaisjärjestelmissä ilmaistu pötsissä sulaneen orgaanisen aineen määrää kohti. Eri järjestelmät poikkeavat hieman laskentatavoissa ja mahdollisten vähennystermien osalta.

Satakertatekniikka (Huhtanen ym. 1997, Ahvenjärvi ym. 2000) on tuottanut aikaisempaa luotettavampaa tietoa pötsin valkuaismetaboliasta pääasiassa sen vuoksi, että ruokasulan virtaus on määritetty kolmoismerkkiainesysteemillä. Aineistosta tehdyssä meta-analyysissä (Broderick ym. 2010) mikrobivalkuaissynteesin tehokkuus oli keskimäärin 148.4 (SE=2.49) ja $142.2(\mathrm{SE}=2.41)$ g per kg pötsissä todellisesti sulanutta orgaanista ainetta (OMTDR) ja koko ruoansulatuskanavassa ylläpitotasolla sulanutta orgaanista ainetta kohti $\left(\mathrm{dOM}_{\mathrm{m}}\right)$. Koska käytännössä ei voida määrittää OMTRD:ta, käytäntöä varten mikrobisynteesin laskenta on perustettava $\mathrm{dOM}_{\mathrm{m}}$ :lle, mahdollisesti korjattuna komponenteilla, jotka tuottavat vähän tai eivät lainkaan energiaa ATP:n muodossa (maitohappo, VFA, pötsissä hajoamaton rehuvalkuainen (RUP), rasva, pötsin jälkeen sulava tärkkelys ja kuitu).

Mikrobisynteesin laskentatavan vaikutusta valkuaistuotoksen ennustevirheeseen selvitettiin sekamallin regressionanalyysillä, jossa koe oli satunnaistekijä. Käytännössä malli tarkoittaa ruokinto- 
jen vertailtua samassa karjassa. OIV-saannin lineaarinen ja 2. asteen vaikutus olivat mallin riippumattomia muuttujia. Aineistossa olivat mukana kokeet, joista kaikki malliin mahdollisesti tulevat parametrit oli määritetty (832 ruokintaa, 171 koetta). Mikrobisynteesin tehokkuutena käytettiin 145 g/kg $\mathrm{dOM}_{\mathrm{m}}$, joka vastaa synteesin tehokkuutta sataekerta-aineistossa kuiva-aineen syönnin ollessa 20-21 kg/pv. Mikrobisynteesin substraatista $\left(\mathrm{dOM}_{\mathrm{m}}\right)$ määrästä vähennettiin käymishapot $(\mathrm{TA})$, raakarasva (EE) ja RUP; jokainen substraatti erikseen tai kaikkina mahdollisina yhdistelminä. Eri vaihtoehdoissa synteesin tehokkuuslukua muutettiin siten, että mikrobivalkuaisen kokonaismäärä oli vakio; ts. mikrobivalkuaisen osuus OIV:n saannista oli vertailuissa sama. Mikrobivalkuaisen aminotypen osuutena käytettiin 75 \% nykysysteemin 70 \% sijasta. Tämä muutos vastaa MTT:n tutkimusten tuloksia ja osittain kompensoi alentuneen synteesin tehokkuuden vaikutusta laskennalliseen OIV:n saantiin.

Kaikkien mallien ennustevirheet olivat pieniä (noin 18 g/pv, Taulukko 1), joka on suunnilleen sama kuin valkuaistuotoksen 90 \%:n luottamusväli change-over kokeissa. Laskettaessa mikrobivalkuainen $\mathrm{dOM}_{\mathrm{m}}$ :n perusteella hieman paransi mallia nykyiseen laskentatapaan (dCHO + RDP) verrattuna. Vaikka ennustevirhe (RMSE) hieman pieneni, kun fermentoituva substraatti korjattiin käymishappojen perusteella, AIC:n perusteella arvioituna säilörehujen happojen vähentäminen huononsi ennustetta. Kun vastaava analyysi tehtiin ainoastaan karkearehufaktoreita (sulavuus, käymislaatu ym.) sisältävällä aineistolla, happokorjaus huononsi ennustetta (Rinne ym. 2009). Pienempi vaikutus laajemmassa aineistossa voi johtua siitä, että mikrobivalkuaisen osuus OIV:n saannista oli ym. julkaisussa käytetyssä mallissa (MTT 2006) suurempi kuin tässä laskelmassa käytetty. Tässä aineistossa regression leikkauspiste oli huomattavasti suurempi korjattaessa $\mathrm{dOM}_{\mathrm{m}}$ käymishappojen osalta. Koska leikkauspiste merkitsee ylläpitotarvetta, happokorjaus näyttäisi johtavan biologisti virheellisempään malliin. Koska säilörehun hapot eivät tuota mikrobeille käyttökelpoista energiaa ja mikrobisynteesi vähenee rehun happopitoisuuden noustessa (Jaakkola ym. 2006), valkuaistuotosennusteen pitäisi parantua korjattaessa $\mathrm{dOM}_{\mathrm{m}}$ käymishappojen suhteen. Toisaalta säilörehun maitohappo tuottaa pötsissä runsaasti propionihappoa, joka on märehtijöiden tärkein glukoosin esiaine. Runsaampi glukoosin saanti voi vähentää aminohappojen käyttöä maksan glukoosin tuotannossa, jolloin aminohappojen hyväksikäyttö kudosmetaboliassa tehostuu.

Taulukko 1. Mikrobisynteesin laskentatavan vaikutus valkuaistuotoksen ennustemalleihin (Valkuaistuotos $=\mathrm{A}+\mathrm{BX}+\mathrm{CX}^{2}$ )

\begin{tabular}{lccccccccc}
\hline & A & SE & P-arvo & B & SE & C & SE & RMSE & AIC \\
\hline $\mathrm{dCHO}^{2}$ RDP & -131 & 50.6 & 0.01 & 771 & 63.0 & -106 & 19.8 & 18.4 & 8145.5 \\
$\mathrm{dOM}_{\mathrm{m}}$ & -119 & 47.6 & 0.01 & 774 & 59.2 & -112 & 18.5 & 18.3 & 8137.8 \\
$\mathrm{dOM}_{\mathrm{m}}$ - TA & -42 & 44.5 & 0.35 & 704 & 55.0 & -100 & 17.3 & 18.0 & 8150.3 \\
$\mathrm{dOM}_{\mathrm{m}}$ - EE & -107 & 47.1 & 0.02 & 761 & 58.4 & -109 & 18.3 & 18.3 & 8150.0 \\
$\mathrm{dOM}_{\mathrm{m}}$ - RUP & -128 & 49.7 & 0.01 & 767 & 61.9 & -104 & 19.4 & 17.9 & 8107.6 \\
$\mathrm{dOM}_{\mathrm{m}}$ - TA -EE & -35 & 44.3 & 0.43 & 699 & 54.5 & -100 & 17.1 & 18.2 & 8178.3 \\
$\mathrm{dOM}_{\mathrm{m}}$ - TA -RUP & -60 & 47.2 & 0.21 & 712 & 58.4 & -98 & 18.4 & 17.9 & 8143.7 \\
$\mathrm{dOM}_{\mathrm{m}}$ - EE - RUP & -120 & 49.6 & 0.02 & 759 & 61.6 & -103 & 19.4 & 18.1 & 8132.2 \\
$\mathrm{dOM}_{\mathrm{m}}$ - TA -EE - RUP & -55 & 47.3 & 0.25 & 713 & 58.3 & -100 & 18.3 & 18.3 & 8189.7 \\
\hline
\end{tabular}

$\mathrm{SE}=$ keskivirhe

RMSE = jäännösvirhe (korjattu kokeen satunnaisvaikutuksen suhteen)

AIC $=$ Akaiken informaatiokriteeri (pienempi on parempi)

$\mathrm{dCHO}=$ sulavat hiilihydraatit $(\mathrm{kg} / \mathrm{pv})$

$\mathrm{RDP}=$ pötsissä hajoava valkuainen $(\mathrm{kg} / \mathrm{pv})$

$\mathrm{dOM}_{\mathrm{m}}=$ sulava orgaaninen aine ylläpitotasolla määritettynä $(\mathrm{kg} / \mathrm{pv})$

$\mathrm{TA}=$ kokonaishapot $(\mathrm{kg} / \mathrm{pv})$

$\mathrm{EE}=$ raakarasva $(\mathrm{kg} / \mathrm{pv})$

RUP = pötsissä hajoamaton valkuainen $(\mathrm{kg} / \mathrm{pv})$ 
Rasvan vähentäminen $\mathrm{dOM}_{\mathrm{m}}$ :sta ei parantanut valkuaistuotoksen ennustetta. Teoriassa rasvakorjauksen pitäisi parantaa valkuaistuotoksen ennustetta, sillä pötsimikrobit eivät saa rasvasta energiaa. Syynä ristiriitaan voi olla se, että rehuannoksen rasvapitoisuus on yleensä pieni ja sen vaihtelu vähäistä. Lisäksi on mahdollista, että lisääntynyt rasvan saanti inhiboi pötsin alkueläimiä, jolloin typen sisäinen kierto ja siitä aiheutuvat tappiot pötsissä vähenevät.

Sekä AIC:n että RMSE:n perusteella arvioituna valkuaistuotoksen ennustemalli parani, kun $\mathrm{dOM}_{\mathrm{m}}$ :sta vähennettiin RUP. Tämä johtuu siitä, että kun RUP on mukana $\mathrm{dOM}_{\mathrm{m}}$ :ssa, se tulee otetuksi huomioon kahteen kertaan OIV:n saantia laskettaessa. Siten $\mathrm{dOM}_{\mathrm{m}}: \mathrm{n}$ korjaus RUP:n suhteen on perusteltu. Tämä korjaus ei myöskään vaadi lisää analyysejä, sillä se voidaan tehdä rehutaulukoiden hajoavuusarvojen perusteella. Kun analyysi tehtiin koko aineistossa, RUP-korjaus vähensi valkuaistuotoksen ennustevirhettä sekä nykyiseen (MTT 2006) OIV-malliin (18.91 v. 19.35) että uudistettuun alemmalla synteesin tehokkuudella ( 145 per $\mathrm{kg} \mathrm{dOM}_{\mathrm{m}}$ ) laskettuun malliin verrattuna (18.91 v. 19.19). Saman mikrobivalkuaistuotannon määrän saavuttamiseksi synteesin tehokkuuslukuna käytettiin $152 \mathrm{~g} \mathrm{~kg}$ $\left(\mathrm{dOM}_{\mathrm{m}}-\mathrm{RUP}\right)$. Nykyiseen käytössä olevaan malliin verrattuna uudella mallilla on kaksi etua: se hieman parantaa ennustetta (1) ja se on yksinkertaisempi laskea (2); ei tarvita esim. raakakuidun pitoisuutta ja sulavuutta

Satakerta-aineistossa mikrobisynteesin tehokkuus lisääntyi rehun syönnin lisääntyessä (Broderick ym. 2010), mutta toisaalta rehuannoksen sulavuus huononee syöntitason noustessa muutoksen ollessa suurempi hyvin sulavilla rehuannoksilla huonosti sulaviin verrattuna (Huhtanen ym. 2009). Kun mallissa otettiin huomioon sekä parantuva mikrobisynteesin tehokkuus että huononeva rehuannoksen sulavuus ruokintatason noustessa, toisen asteen mallin ennustevirhe lisääntyi 18.91:stä 19.44:een. Tulos johtuu osittain siitä, että nämä kaksi tekijää kompensoivat toistensa vaikutuksia. Lisäksi on mahdollista, että $\mathrm{dOM}_{\mathrm{m}}$ :n korjaaminen ruokintason ym. suhteen lisää virhettä verrattuna ylläpitotason $\mathrm{dOM}_{\mathrm{m}}$ :n käyttöön. Kahdella mallilla laskettu OIV:n saanti oli erittäin voimakkaasti keskenään korreloitunut $\left(\mathrm{R}^{2}=0.995\right)$ eli mallin monimutkaistaminen ei tuonut hyödyllistä lisäarvoa. Koska monimutkaisemmasta mallista ei ole etua yksinkertaisempaan verrattuna, käytännön rehujen arviointiin ja ruokinnan suunnitteluun tarkoitettua mallia ei ole tarpeen monimutkaistaa.

Mikrobisynteesin tehokkuuden ollessa $152 \mathrm{~g}$ per $\mathrm{kg}\left(\mathrm{dOM}_{\mathrm{m}}-\mathrm{RUP}\right) \mathrm{PVT}$ oli nolla (valkuaisen saanti - pötsistä virtaava valkuainen $=0$ ), kun maidon ureapitoisuus oli 17.5-18.0 mg/100 ml. Dieetin RV- ja RDP-pitoisuudet olivat 127 ja 102 g/kg ka. Satakerta-aineistossa mitattu PVT oli 0 maidon urean ollessa 17.9 mg/100 ml sekä RV- ja RDP-pitoisuudet vastaavasti 147 ja 106 g/kg ka. Maidon ureapitoisuuden ja rehuannoksen RDP-pitoisuuden perusteella näyttäisi siltä, että todellinen PVT on lähellä nollaa mallin ennustaessa nollaa. Suurempi RV-pitoisuus pötsin 0-taseessa johtuu osittain suuremmasta ruokintatasosta (synteesi tehostuu syönnin lisääntyessä) ja osittain siitä, että mitatussa taseessa on mukana myös endogeenista valkuaista. Tämä tarkoittaa sitä, että kun kokeessa mitattu pötsin $\mathrm{PVT}=0$, niin ammoniakin imeytyminen ylittää pötsiin sisäisen kierron mukana tulevan typen määrän.

Maidon ureapitoisuus on erittäin hyvä PVT:n mittari; kun ureapitoisuus ylittää 18 niin erityistä huolta pötsissä hajoavan typen riittävyydestä ei ole. On erittäin harvinaista, että laskennallinen OIV:n tarve ylittyy PVT:n ollessa negatiivinen. Tässä aineistossa oli noin 30 ruokintaa 992 ruokinnasta, joilla PVT oli negatiivinen. Kun mikrobi-OIV:tä vähennettiin negatiivista PVT:tä vastaava määrä, mallin ennustevirhe lisääntyi 18.91:stä 19.28:aan. Tämä viittaa siihen, että pötsin sisäinen kierto pystyy ainakin osittain kompensoimaan negatiivisen PVT:n eikä synteesi vähene tai vähennys on pienempi kuin negatiivinen PVT:n määrä. Keskimääräisellä ruokinnalla 1 g/kg KA rehuannoksen PVT-pitoisuudessa vastaa noin $0.4 \mathrm{mg} / 100 \mathrm{ml}$ muutosta maidon ureapitoisuudessa. Jos maidon ureapitoisuus on 14, tarvitaan noin $10 \mathrm{~g} / \mathrm{kg}$ KA lisää pötsissä hajoavaa valkuaista 0-taseen saavuttamiseksi. Koska mikrobisynteesin tehokkuus on kasvavilla naudoilla ( $>200 \mathrm{~kg}$ ) alemman ruokintatason vuoksi huonompi, niiden PVT- ja yleensä valkuaisruokinnan suositukseksi riittänee > - 10 g PVT/kg KA.

\section{Ohitusvalkuainen}

Mikrobivalkuaisen ohella pötsin hajoamatta ohittava rehuvalkuainen tuottaa ohutsuolesta imeytyviä aminohappoja. Tutkimuksessa ohitusvalkuaiseen on kiinnitetty paljon enemmän huomiota kuin mikrobivalkuaiseen huolimatta sen selvästi vähäisemmästä merkityksestä; suureksi osaksi todennäköisesti helpon tutkimusmenetelmän (nailonpussi-inkubaatio) vuoksi.

Nailonpussimenetelmällä saatuja hajoavuustuloksia on hyvin harvoin validoitu tuotantokokeissa lypsylehmillä. Usein luotetaan enemmän hajoavuustuloksiin eikä haluta kiinnittää huomio pus- 
simenetelmään perustuvien valkuaisarvojen ja tuotantokokeiden tulosten ristiriitaan. Äskettäin julkaistussa meta-analyysissä (Ipharraguerre ja Clark 2005) ero maitotuotoksessa vähemmän hajoavien rehujen eduksi oli vain noin $1 \%$. Huhtasen ja Hristovin (2009) meta-analyysissä valkuaisen hajoavuuden vaikutus maitotuotokseen ja typen hyväksikäyttöön oli hyvin pieni, kun NRC:n (2001) mukaan arvioitu valkuaisen hajoavuus lisättiin malliin energian (TDN) ja raakavalkuaisen saannin lisäksi. Yhden prosenttiyksikön muutos valkuaisen hajoavuudessa vastasi 1.4 ja 1.8 gramman lisäystä valkuaistuotoksessa Pohjois-Amerikan ( $\mathrm{n}=732$ dieettiä) ja Pohjois-Euroopan $(\mathrm{n}=998)$ tuotantokoeaineistossa. OIV:n saantina muutos vastaa nykyisellä keskimääräisellä lypsylehmän ruokintatasolla noin 22 g/pv eli hajoavuuden alentamisella OIV:n (MP:n) marginaali hyväksikäyttö oli ainoastaan 6-8 \%. Valkuaisjärjestelmien hyväksikäytön oletusarvo on yleensä 60 - 70 \%; Suomen nykyisessä järjestelmässä $69 \%$.

Yllä mainitussa analyysissä mikrobivalkuaisesta peräisin oleva MP ennusti valkuaistuotoksen vähintään yhtä hyvin kuin kokonais-MP eli ennusteen tarkkuuden kannalta ohitusvalkuainen ei tuottanut mitään lisäarvoa vaan jopa saattoi hieman lisätä virhettä. Kun valkuaistuotosta selitettiin mikrobija rehu-MP:lla malli parani huomattavasti. Mielenkiintoista on se, että molemmissa aineistoissa mikrobi-MP:n kulmakerroin (=hyväksikäyttö) oli noin 5-kertainen rehu-MP:hen verrattuna. Rehu-MP:n hyväksikäyttö oli 9.6 ja 14.2 \% näissä aineistossa. Rehu-MP:n hyväksikäytön voi olettaa olevan huonompi kuin mikrobi-MP:n, koska jälkimmäinen on suorassa suhteessa energian saantiin. Lisäksi rehuvalkuaisen aminohappokoostumus on usein huonompi kuin mikrobivalkuaisen. Näin suuri ero mikrobi- ja rehu-MP:n hyväksikäytössä tuskin voi olla, etenkään pelkästään hajoavuuden eroista johtuvan MP:n osalta, vaan huonon näennäinen hyväksikäyttö selittynee osittain saannin erojen yliarvioinnilla.

Suomen 1995 OIV-systeemin validoinnissa valkuaistuotoksen ennustevirhe oli pienempi laskettaessa OIV-arvot käyttäen vakiohajoavuutta kaikille rehuille verrattuna OIV-arvoihin, jotka perustuivat ko. kokeissa nailonpussimenetelmällä määritettyihin hajoavuuksiin (Tuori ym. 1998). Myöhemmässä vertailussa (Schwab ym. 2005) Saksan systeemi, jossa mikrobivalkuainen on ME-saannin funktio ja ohitusvalkuainen rehun ureattoman raakavalkuaisen funktio (=vakio hajoavuus), ennusti valkuaistuotoksen paremmin kuin muut vertailussa mukana olleet systeemit Suomen systeemiä lukuun ottamatta sekä suomalaisella että amerikkalaisella ruokintakoeaineistolla. Säilörehun liukoisen N:n osuuden lisääminen ennustemalliin toiseksi tekijäksi ei parantanut valkuaistuotoksen ennustetta, kun säilörehun OIV laskettiin vakiohajoavuudella (Huhtanen ym. 2008). Jaettaessa säilörehun liukoinen N ammoniakkiin ja liukoiseen ei-ammoniakkityppeen (SNAN; vapaat aminohapot, peptidit, liukoinen puhdasvalkuainen), ainoastaan jälkimmäinen vaikutti negatiivisesti valkuaistuotokseen ja typen hyväksikäyttöön sekä lisäsi maidon ureapitoisuutta. Johtopäätöksenä oli, että säilörehun SNAN (nailonpussimenetelmän liukoinen fraktio) ja liukenematon valkuainen olivat samanarvoisia lehmän OIV:n lähteenä. Samaten säilörehun vakiohajoavuuteen perustuva OIV ennusti maitovalkuaisen tuotannon paremmin, kuin empiiriseen rehun kuiva-aine-, valkuais- ja kuitupitoisuuteen sekä liukoisen typen osuuteen perustuvalla mallilla ennustettuun hajoavuuteen perustuva OIV. Malli perustuu 130 säilörehun nailonpussihajoavuuksiin (Yan \& Agnew 2004).

Kuviossa 1 on esitetty valkuaistuotoksen ennustevirheet, kun se ennustettiin yksinkertaisella regressioanalyysillä käyttäen riippumattomana muuttuja ravintoaineiden saantiin liittyviä parametreja ( $\mathrm{n}=992$ ruokintaa). Raakavalkuaisen saanti oli huonoin valkuaistuotoksen ennustaja, mikä johtuu suureksi osaksi vaihtelevista pötsimikrobien tarpeen ylittävän hajoavan valkuaisen tappioista. Virhe pieneni 72:een, kun valkuaispitoisuus lisättiin malliin toiseksi tekijäksi. Valkuaispitoisuuden regressiokerroin oli -4.4; eli kun valkuaisen saanti (g/pv) on vakio, tuotos on sitä suurempi mitä pienempi dieetin valkuaispitoisuus on. Tämä johtuu siitä, että mitä pienemmällä pitoisuudella tietty valkuaisen saanti saavutetaan, sitä suurempi on kuiva-aineen syönti, energian saanti ja mikrobivalkuaisen tuotanto. Kuiva-aineen saanti ennustikin valkuaistuotoksen paremmin kuin RV:n saanti. Ennuste parani edelleen, kun riippumattomana muuttujana oli energian saanti. Mielenkiintoista on se, että NRC:n valkuaismalli ennusti tuotoksen huonommin kuin ME:n tai jopa KA:n saanti. Tämä tarkoittaa sitä, että rehuMP:n laskeminen NRC:n (2001) esittämällä tavalla lisäsi ennustevirhettä. NRC:n malli perustuu erittäin laajaan nailonpussimenetelmällä määritettyyn hajoavuusaineistoon. Lisäksi mallissa otetaan huomioon ruokintatason vaikutus valkuaisen pötsihajoavuuteen. Suomen OIV-systeemi ennusti valkuaistuotoksen jonkin verran paremmin kuin ME, mutta rehun sulavuuden huomioon ottaminen (ME v. KA) paransi mallia enemmän kuin hajoamaton rehuvalkuainen (ME v. OIV; ME mikrobisynteesi). Laskettaessa OIV joko käyttäen kaikille rehuille hajoavuutena 75 \% tai karkearehuille 80 \% ja väkire- 
huille 70 \% lisäsi ennustevirhettä jonkin verran. Mixed-mallin analyysissä ero ennustevirheessä uuden mallin ja vakiohajoavuuksilla lasketun OIV:n välillä oli pieni (18.9 v. 19.5 g/pv).

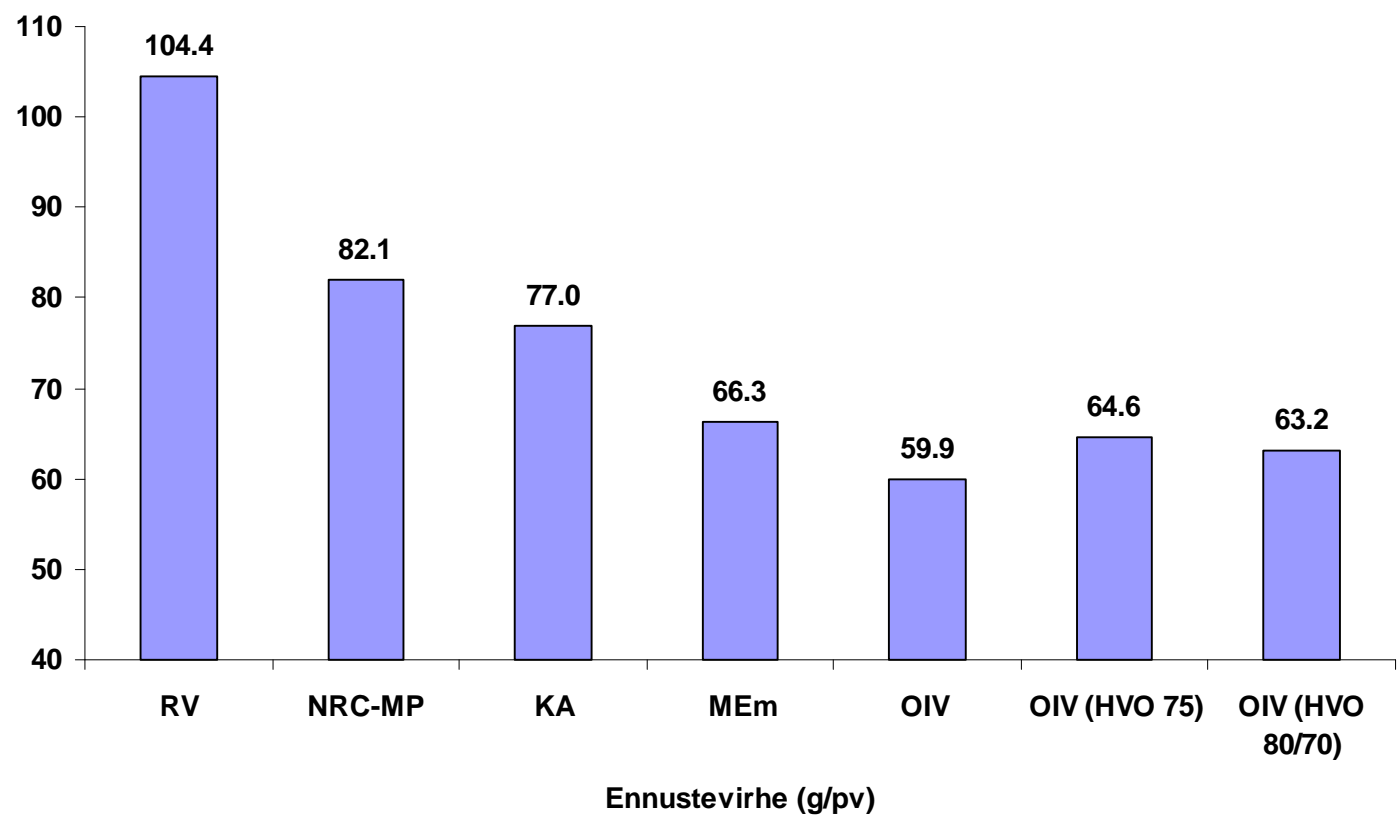

Kuvio 1. Valkuaistuotoksen ennustevirhe yksinkertaisella regressiomallilla. Riippumattomina muuttujina olivat raakavalkuaisen saanti (RV), NRC (2001) mukaan laskettu muuntokelpoinen valkuainen (NRC-MP), kuiva-aineen syönti (KA), muuntokelpoinen energia (ylläpitotason sulavuus) $\left(\mathrm{ME}_{\mathrm{m}}\right)$, OIV:n saanti uudella laskentatavalla (OIV), OIV:n saanti laskettu vakiohajoavuudella (OIV - HVO 75 \% ja OIV:n saanti laskettu vakiohajoavuuksilla (karkearehut 80 \% ja väkirehut 70 \%) (OIV - HVO 80/70)

Edellä esitetyn perusteella vaikuttaa siltä, että nailonpussimenetelmään perustuvien hajoavuuksien tuottama lisäarvo MP:n (OIV) määrittämisessä on varsin vähäinen. Toisaalta tiedetään, että rehujen välillä on eroja niiden valkuaisen pötsihajoavuudessa (esim. urea v. kalajauho). Mahdollisia syitä ristiriitaan ovat mm. huonontunut ohitusvalkuaisen sulavuus, aminohappojen muuttuminen käyttökelvottomaan muotoon tai nailonpussimenetelmän heikkouksista johtuvat virhearviot RUP:n saannissa. Satakerta-aineiston meta-analyysin (Broderick ym. 2010) mukaan rehuannosten väliset erot valkuaisen ohitusvalkuaisen (RUP) määrässä olivat selvästi pienempiä kuin NRC:n (2001) mukaan lasketut (Kuvio 2). Keskimäärin NRC (2001) yliarvioi ohitusvalkuaisen määrän noin 10 \%, kun rehuvalkuaisen virtaus korjattiin endogeenisen $\mathrm{N}: \mathrm{n}$ suhteen ja oletettiin, että mikrobisynteesi aliarvioitiin keskimäärin 5 \%. Jälkimmäinen korjaus tehtiin sen vuoksi, että käytetty mikrobimerkkiaine $\left({ }^{15} \mathrm{~N}\right)$ aliarvio alkueläintypen virtauksen. Kulmakertoimen virhe on tässä tapauksessa keskiarvon virhettä merkittävämpi, sillä sen mukaan ero rehuvalkuaisen todellisessa pötsihajoavuudessa ovat selvästi pienempiä kuin NRC:n (2001) ennustamat erot. Hajoavuudessa kulmakerroin virhe oli vielä suurempi kuin rehu-N:n virtauksessa (0.32 v. 0.26).

\section{Miksi hajoavuuserot yliarvioidaan}

Nailonpussimenetelmässä on sen huonon laboratorioiden välisen toistettavuuden lisäksi lukuisia virhelähteitä, jotka osittain kompensoivat toisiaan. Lisäksi menetelmän virhelähteitä voidaan yrittää korjata (esim. mikrobikontaminaatio, partikkelihävikki).

Kaksi suurinta puutetta ovat olettamus, että ns. liukoinen a-fraktio olisi täysin hajoavaa. Lukuisilla tutkimusmenetelmillä on osoitettu, että liukoista rehusta peräisin olevaa amino- 


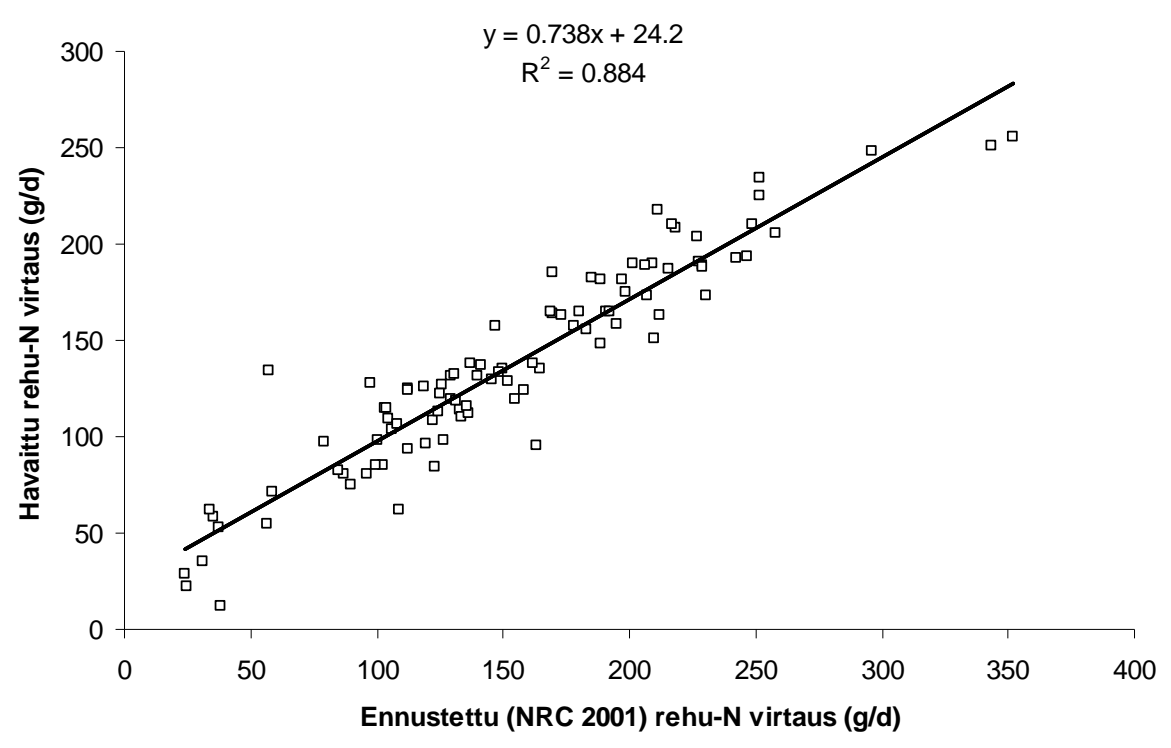

Kuvio 2. Ennustettu (NRC 2001) ja havaittu rehu-N:n virtaus pötsistä (Broderick ym. 2010).

typpeä virtaa pötsistä ulos nestefaasissa. Tämä pienentää rehujen välisiä eroja hajoavuudessa. Toinen virheolettamus hajoavuusmallissa on se, että rehupartikkeleiden virtauksen oletetaan noudattavan ensimmäisen kertaluvun kinetiikkaa yhden poolin mallissa. Rehupartikkelit virtaus pötsistä on valikoivaa; ts. pienten ja pötsissä pitkään viipyneiden partikkeleiden todennäköisyys virrata ulos on suurempi kuin suurten äskettäin syötyjen partikkeleiden. Oikean virtauskinetiikkamallin käyttäminen usein pienentää rehujen välisiä eroja hajoavuuksissa. Karkearehujen valkuaisen hajoavuuserot supistuvat alle puoleen yleisesti käytetyn Ørskov ja McDonald (1979) mallin ennusteista, kun kahden tässä mainitun tekijän vaikutukset otetaan huomioon.

Selitettäessä hajoamattoman rehuvalkuaisen virtausta satakertaan NRC:n (2001) mallin RUP:n ja RDP:n saannilla, regressiokertoimet olivat 0.74 ja 0.09 eli kertoimet poikkesivat merkittävästi mallin oletusarvoista 1.0 ja 0.0; edellinen kerroin tarkoittaa että $26 \%$ hajoamattomasta valkuaisesta oli hajoavaa ja hajoavasta $9 \%$ ohitti pötsin hajoamatta. Vastaavasti ennustettaessa hajoavan valkuaisen pitoisuus NRC:n (2001) RDP- ja RUP-pitoisuudella regressiokertoimet olivat 0.81 ja 0.25 . Tässä edellinen kerroin tarkoittaa, että 19 \% RDP:stä oli RUP:tä ja että 25 \% RUP:stä oli RDP:tä. Näiden regressioanalyysien tulokset ovat johdonmukaisia ym. menetelmän virheiden kanssa.

Kun OIV-PVT -järjestelmä otettiin Suomessa käyttöön vuonna 1995, näihin ongelmiin osattiin kiinnittää ainakin jonkin verran huomioita. Tämän vuoksi esim. käytettiin huomattavasti alempia partikkelin virtausnopeuksia kuin muissa järjestelmissä. Lisäksi kiinnitettiin huomiota siihen, että nailonpussimenetelmällä mitatut erot rehuvalkuaisen hajoavuudessa ja OIV-arvossa eivät toteutuneet ruokintakokeissa ja vaadittiin, että prosessoinnilla alennettu parempi laskennallinen valkuaisarvo on osoitettava tuotantokokeessa ennen kuin alempaa hajoavuutta voidaan virallisesti käyttää.

\section{Yhteenveto ja päätelmät}

Suomen OIV-PVT -järjestelmä on vertailuissa ennustanut maitovalkuaisen tuotoksen paremmin kuin muut vertailuissa mukana olleet järjestelmät. Suurin syy tähän on todennäköisesti se, että mikrobivalkuaisen osuus OIV:n saannista on suurempi eikä pötsissä hajoamattoman valkuaista ylikorosteta luottamalla pelkästään nailonpussimenetelmällä määritettyihin hajoavuuksiin kuten monissa muissa systeemeissä. Vuoden 2006 (MTT 2006) systeemiä voidaan yksinkertaistaa laskemalla mikrobivalkuaisen määrä ylläpitotasolla määritettyä sulavaa orgaanista ainesta kohti ja vähentämällä tästä pötsissä hajoamaton valkuainen. Tällöin päästään eroon täysin tarpeettomasta väkirehun raakakuidun pitoisuuden ja sulavuuden määritystarpeesta. Mikrobisynteesin tehokkuusluvun pienentämisellä poistuu laskennallisesti negatiivisen PVT:n ongelma eli todellinen PVT on nolla laskennallisen arvon ollessa nolla. 
Tilastoanalyysien perusteella monimutkaisemmat korjaukset mikrobeille käyttökelpoisen substraatin määrässä eivät ole perusteltuja.

Meta-analyysit ovat osoittaneet, että valkuaistuotoksen vaihtelu johtuu pääasiassa energian saannin vaihtelusta vahvistaen näin mikrobivalkuaisen keskeistä osuutta. Valkuaisen hajoavuus parantaa valkuaistuotoksen ja typen hyväksikäytön ennustemalleja hieman lisättäessä se malliin kolmantena tekijänä energian ja raakavalkuaisen saannin lisäksi. Tämä osoittaa, että nailonpussimenetelmällä määritetty hajoavuus korreloi rehun todellisen hajoavuuden kanssa eli että hajoavuudessa on eroja. Useissa tapauksissa vakiohajoavuus on parantanut ennusteita rehutaulukoiden hajoavuusarvoihin verrattuna. Tämä johtuu siitä, että vakiohajoavuutta käytettäessä virhe (todellinen hajoavuus - vakio) on pienempi kuin nailonpussimenetelmällä määritetty virhe (todellinen hajoavuus - pussihajoavuus). Vakiohajoavuuden sijasta hieman parempaan tulokseen voitaisiin päästä, jos rehut jaetaan hajoavuuden (\%) perusteella luokkiin: karkearehut (esim. 80), vilja- ja muut energiarehut (esim. 75) ja valkuaisrehut (esim. 65 - 70) ja urea (100). Valkuaisen hajoavuusarvojen määrittäminen nailonpussimenetelmällä on mielestäni turhaa ja menetelmän käyttö tähän tarkoitukseen olisi syytä lopettaa. Elleivät tutkijat pysty kehittämään parempaa ja toistettavampaa menetelmää rehuvalkuaisen pötsihajoavuuden määrittämiseen, hajoavuusarvojen suhteen kannattaisi mieluummin mennä edellä kuvattuun yksinkertaistamiseen.

Rehujen valkuaisarvon määrittämisen keskeinen tavoite on, että tuottajilla ja ruokinnan suunnittelijoilla on käytössään rehuarvot, jotka vastaavat mahdollisimman hyvin niiden tuotantovaikutusta. On mahdollista, että joidenkin rehujen "todellinen” OIV on suurempi kuin systeemin ennustama, mutta aminohappojen hyväksikäyttö on huonompi esim. huonon aminohappokoostumuksen tai riittämättömän glukoosin saannin vuoksi. Käytännön kannalta valkuaistuotoksen erojen tarkka ennustaminen on tärkeämpää kuin todellisen OIV-saannin ennustaminen. Nykyisissä systeemeissä hyväksikäyttö on "musta laatikko"; sen oletetaan olevan vakio vaikka siinä todennäköisesti on suurta vaihtelua. Hajoavuuden osalta ollaan lähes samassa tilanteessa; siinä on vaihtelua mutta todellista vaihtelua ei osata mitata luotettavasti. Monimutkaisempien MP-mallien ongelmaksi voi muodostua ennustevirheen lisääntyminen, kun lisätään malliin teoreettisesti oikeita elementtejä (esim. käymishapot, ohitustärkkelys, rasva) mutta ei oteta huomioon niiden vaikutuksia aineenvaihdunnassa. Käyttäjän kannalta on eduksi, kun voidaan tulla toimeen mahdollisimman vähillä analyyseillä ja että tehdään oikeita analyysejä. Kun kokeen sisäistä valkuaistuotoksen vaihtelua selitettiin väkirehun määrän lisäksi säilörehun syönti-indeksillä (a), väkirehun valkuaispitoisuudella (b) ja valkuaisen hajoavuudella (c), yhden hajonnan yksikön vaihtelu vastasi 45 (a), 20 (b) ja 14 (c) g/pv maitovalkuaisen tuotannossa. Säilörehun analysointi on siten huomattavasti tärkeämpää kuin väkirehujen, joiden osalta voidaan käyttää taulukkoarvoja. Ehdotetun uuden OIV-PVT -järjestelmän etuna on sen yksinkertaisuus ja vähäinen rehutietojen tarve verrattuna muiden pohjoismaiden käyttöön ottamaan NorFor-järjestelmään. MTT vastaa MMM:n päätöksellä rehujen virallisista laskentaperusteita Suomessa ja ajantasainen tieto niistä löytyy Rehutaulukot-verkkopalvelusta (www.mtt.fi/rehutaulukot).

\section{Kirjallisuus}

Ahvenjärvi, S., Vanhatalo, A. Huhtanen, P. \& Varvikko, T. 2000. Determination of forestomach digestion in lactating dairy cows by omasal or duodenal sampling. British Journal of Nutrition. 83: 67-77.

Broderick, G.A., Huhtanen, P., Ahvenjärvi, S., Reynal., S.M. \& Shingfield, K.J. 2010. Quantifying Ruminal Nitrogen Metabolism Using Omasal Sampling in Lactating Dairy Cows-A Meta-analysis. Submitted to Journal of Dairy Science.

Huhtanen, P. 2005. Critical aspects of feed protein evaluation systems for ruminants. Journal of Animal and Feed Sciences 14, Supplement 1: 145-170.

Huhtanen, P., Brotz, P.G. \& Satter, L.D. 1997. Omasal sampling technique for assessing fermentative digestion in the forestomach of dairy cows. Journal of Animal Science 75:1380-1392.

Huhtanen, P. \& Hristov, A.N. 2009. A meta-analysis of the effects of protein concentration and degradability on milk protein yield and milk N efficiency in dairy cows. Journal of Dairy Science 92:3222-3232.

Huhtanen, P., Rinne, M. \& Nousiainen. 2009. A meta-analysis of feed digestion in dairy cows. 2. the effects of feeding level and diet composition on digestibility. Journal of Dairy Science 92: 5031-5042.

Huhtanen, P., Rinne, M. \& Nousiainen, J. 2008. Effects of silage soluble N components on metabolizable protein concentration: a meta-analysis of dairy cow production experiments. Journal of Dairy Science 91:11501158. 
Jaakkola, S., Kaunisto, V. \& Huhtanen, P. 2006. VFA proportions and microbial protein synthesis in the rumen of cattle receiving grass silage ensiled with different rates of formic acid. Grass and Forage Science 61: 282-292.

Ipharraguerre, I. R. \& Clark, J.H. 2005. Varying protein and starch in the diet of dairy cows. II. Effects on performance and nitrogen utilization for milk production J. Dairy Sci. 88: 2556-2570.

Madsen J. 1985. The basis for the proposed Nordic Protein Evaluation System for ruminants. The AAT-PBV system. Acta Agriculturae Scandinavica, Supplement 25: 9-29.

MTT. 2006. Rehutaulukot ja ruokintasuositukset -verkkopalvelu. Viitattu 10.11.2009.

www.mtt.fi/rehutaulukot

NRC. 2001. National Research Council. Nutrient Requirements of Dairy Cattle. $7^{\text {th }}$ revised Edition. National Academy Press, Washington, DC. pp. 381.

Ørskov E.R. \& McDonald I. 1979. The estimation of protein degradability in the rumen from incubation measurements weighted according to rate of passage. Journal of Agricultural Science 92, 499-503

Rinne, M., Huhtanen, P. \& Nousiainen, J. 2009. Effects of silage effective protein degradability and fermentation acids on metabolizable protein concentration: A meta-analysis of dairy cow production experiments. Journal of Dairy Science 92: 1633-1642.

Schwab, C.G., Huhtanen, P., Hunt, C.W. \& Hvelplund, T. 2005. Nitrogen Requirements of Cattle. In: R. Pfeffer and A. Hristov (eds). Interactions between Cattle and the Environment. CAB International. pp. 13-70.

Tuori, M., Kaustell, K. \& Huhtanen, P. 1998. Comparison of the protein evaluation systems of feed for dairy cows. Livestock Production Science 55:33-46.

Yan, T. \&. Agnew, R. E. 2004. Prediction of nutritive value of grass silages: II. Degradability of nitrogen and dry matter using digestibility, chemical composition and fermentation data. Journal of Animal Science 82:13801391. 